\title{
Društvo hrvatskih umjetnika Medulić - artikulacija programa
}

\section{Bulimbašić, Sandi}

Source / Izvornik: Institucije povijesti umjetnosti : zbornik 4. kongresa hrvatskih povjesničara umjetnosti, 2019, 249 - 257

Conference paper / Rad u zborniku

Publication status / Verzija rada: Published version / Objavljena verzija rada (izdavačev PDF)

https://doi.org/10.31664/z4khpu.33

Permanent link / Trajna poveznica: https://urn.nsk.hr/urn:nbn:hr:254:538990

Rights / Prava: Attribution 4.0 International/Imenovanje 4.0 međunarodna

Download date / Datum preuzimanja: 2023-04-26

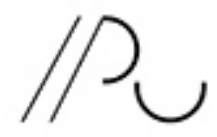

INSIITUTR ZA POVIJEST UMJETNOST
Repository / Repozitorij:

PODEST - Institute of Art History Repository

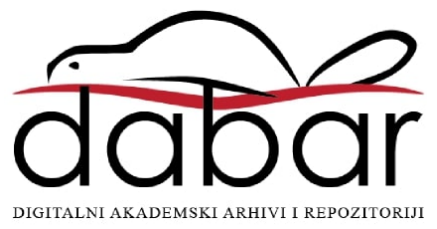




\section{Društvo hrvatskih umjetnika Medulić-artikulacija programa}

\section{Uvod}

U povijesti umjetničkih udruženja i umjetnosti moderne u Hrvatskoj Društvo hrvatskih umjetnika Medulić ima istaknutu ulogu i značenje, ali je tek nedavno monografski obrađeno. ${ }^{1}$ Prethodna istraživanja Društvo su tumačila redukcijski kroz ideološku odrednicu nacionalne ideje jugoslavenstva i individualne tematsko-stilske doprinose protagonista hrvatskoj umjetnosti moderne, zanemarujući svu širinu njegova djelovanja. ${ }^{2}$ Izostao je važan aspekt teme-valorizacija i interpretacija uloge Društva u vremenu u kojemu je djelovalo i pomacima koje je ostvarilo i to ne samo u nacionalnim okvirima. ${ }^{3}$ Cjelovitim sagledavanjem uloge Društva Medulić u povijesti hrvatske umjetnosti 20. stoljeća, kroz različite idejne i praktične segmente njegova djelovanja, uočava se dalekosežna uloga Društva u zaštiti profesionalnih interesa umjetnika, organizaciji umjetničkog života i razvoju umjetnosti u Hrvatskoj. ${ }^{4}$

\section{Zasluge i doprinos Društva Medulić organizaciji umjetničkog života u Hrvatskoj}

Zasluge i doprinos medulićevaca organizaciji umjetničkog života u Hrvatskoj u prvim dvama desetljećima 2o. stoljeća najbolje je sagledati ako njihovo djelovanje u praksi usporedimo s ciljevima definiranim u pravilniku Društva. ${ }^{5}$ Većinu navedenih ciljeva pokušali su ostvariti, ali je realizacija nekih-izdavačka djelatnost, osnivanje knjižnice i galerije, gradnja umjetničkog paviljona-izostala ili je tek dijelom ostvarena zbog nedostatka sredstava te povijesnih, političkih i gospodarskih okolnosti u zemlji, posebice u Dalmaciji.

Osim unapređenja hrvatske umjetnosti-afirmacijom modernizma, umjetničke individualnosti i slobode naspram dotad vladajućeg akademizma realističkih i verističkih tendencija, što zahvaljujemo individualnim stilskim doprinosima protagonista koji se školuju u inozemstvu, odakle u domovinu

\section{Sandi Bulimbašić}

Konzervatorski odjel u Splitu Uprava za zaštitu kulturne baštine Ministarstvo kulture Republike Hrvatske sbulimbasic@gmail.com

https://orcid.org/oooo-ooo3-I375-4074
I SANDI BULIMBAŠIĆ, Društvo hrvatskih umjetnika „Medulić" (I908.- I9I9.), doktorski rad, Zagreb, Filozofski fakultet Sveučilišta u Zagrebu, 20I4.; SANDI BULIMBAŠIĆ, Društvo hrvatskih umjetnika „Medulić” (I908.-г9I9.): umjetnost i politika, Zagreb, 2016.

2 VESNA NOVAK OŠTRIĆ, Nejunačkom vremenu u prkos. Društvo hrvatskih umjetnika „Medulić” ı9o8-ı9ı6, 8. Historijska retrospektivna izložba Moderne galerije Zagreb, katalog izložbe, (ur.) Marino Tartaglia, Zagreb, I962.; IGOR ZIDIĆ, Pokreti s kraja stoljeća, u: Razlog, 9 (I962.), 7I7-738; o Meduliću 732-738; GRGO GAMULIN, Hrvatsko slikarstvo XX. stoljeća, sv. I, Zagreb, I997., 65-67; JELENA USKOKOVIĆ, Monumentalizam kao struja hrvatske moderne i Mirko Rački, u: Život umjetnosti, 29/30 (I980.), 4-25.

3 Primijetio je to i dio kritike u osvrtima na izložbu i katalog izložbe Nejunačkom vremenu uprkos autorice Vesne Novak Oštrić u Zagrebu I962. Vidi: VERA HORVAT PINTARIĆ, Smisao retrospektiva, u: Telegram, 5. listopada I962., 5, pretisak u: Kritike i eseji. I952.-2002. Izbor, Zagreb, 20I2., I55-I56, I55. Opširnije u: SANDI BULIMBAŠIĆ (bilj. I, 20I6.), 3I7-3I8. O Društvu u kontekstu srednjoeuropske umjetnosti: SANDI BULIMBAŠIĆ (bilj. I, 20I6.), 348-359.

4 Opširnije o temi u poglavlju knjige objavljenoj u studenom 2oI6., istovremeno s održavanjem 4. kongresa hrvatskih povjesničara umjetnosti. SANDI BULIMBAŠIĆ (bilj. I, 20I6.), 3I5-329.

5 Pravilnik Hrvatskog umjetničkog društva „Medulić” u Splitu, Split, ı9ıо., 3-4, Arhiv Konzervatorskog odjela u Splitu (dalje: AKO-ST), br. I2/ı9ıо. Opširnije: SANDI BULIMBAŠIĆ (bilj. I, 2OI4.), 69. 
donose nove, suvremene umjetničke ideje, ${ }^{6}$ najveći doprinos Društvo je ostvarilo na polju organizacije i podizanja kvalitete umjetničkog života te u zaštiti profesionalnih interesa članova, odnosno temeljnih egzistencijalnih pitanja umjetničkog staleža. Ujedinjenjem dalmatinskih umjetnika te regulacijom i ujednačavanjem njihovih prava s pravima banovinskih umjetnika okupljenih u Društvu umjetnosti i hrvatskom odsjeku Saveza Lada Društvo Medulić uvelike je zaštitilo staleške interese svojih članova i umjetničke profesije općenito osiguravši zdravu konkurenciju na polju izložbene djelatnosti i tržišta umjetnina u Hrvatskoj i inozemstvu, što je, uostalom, i bila svrha osnutka Društva. U okviru mogućnosti, ali i osobnog zalaganja članova, Društvo je moralno i materijalno pomagalo i mlade umjetničke talente. ${ }^{7}$

U skladu s pravilnikom Društvo Medulić često je iznosilo stručna mišljenja i sudove o pojedinim umjetničkim pitanjima. Oglasilo se tako priopćenjem u "slučaju Milčinović” I9Io. ${ }^{8}$ te prilikom natječaja za ukrašavanje zgrade Sveučilišne knjižnice u Zagrebu I9ıI., zahtijevajući da se izvedba osigura putem javnog natječaja, a ne protekcionizmom. Izdvaja se stručno mišljenje koje je Društvo objavilo u tisku prilikom natječaja za spomenik Strossmayeru Igog. godine. Uvjeti natječaja koji se navode u priopćenju i danas su, što se tiče stručnosti, vrijedni citiranja. ${ }^{9}$ Posredno i kritički, Društvo je sudjelovalo u raspravama o važnim umjetničkim pitanjima i tekstovima i karikaturama objavljenim u splitskom časopisu Duje Balavac, u kojem je urednička medulićevska trojka, slikari Ante Katunarić, Emanuel Vidović i Virgil Meneghello Dinčić, često iznosila stajališta o urbanističkim, arhitektonskim i umjetničkim intervencijama u Splitu i Hrvatskoj podižući tako likovnu i društvenu svijest građana.

Svjesni obrazovnog i pedagoškog aspekta umjetnosti, ali i reklamiranja Društva radi privlačenja novih članova koji bi materijalno podupirali njegov rad, medulićevci su, kao i Društvo umjetnosti, jednom godišnje priređivali zabave i druženja za članove, uz lutriju na kojoj su se sretnim dobitnicima darovala umjetnička djela članova Društva. Kao svojevrsni nastavak tradicije Književno-umjetničkog kluba utemeljena u Splitu I9oI. često su organizirali stručna predavanja te čitanja novih dramskih i književnih tekstova članova (Ive Vojnovića, Milana Begovića i drugih), najčešće u kavani Troccoli na splitskoj Pjaci. ${ }^{10}$ Skupni posjeti izložbama uz stručno vodstvo i stručna putovanja, iako pravilnikom definirani ciljevi, nisu dokumentirani osim posjeta Međunarodnoj izložbi u Rimu ıgI I. u organizaciji časopisa Jug i urednika Milana Marjanovića. ${ }^{11}$

Izdavačka djelatnost, jedan od (pravilnikom definiranih) važnih ciljeva Društva, nije se uspjela realizirati zbog nedostatka novca. Osim kataloga izložaba Društva Medulić nisu dokumentirana i neka druga izdanja Društva. Dvije inicijative iz I9I3. godine-izdavanje brošure Koste Strajnića o arhitekturi i umjetničkom obrtu, na poticaj autora i Ivana Meštrovića, te izdavanje monografije slovenskog slikara Ivana Grohara uz postumnu slikarevu retrospektivnu izložbu u Splitu, na inicijativu Vidovića-nisu se ostvarile.
6 Kod većine umjetnika riječ je o impulsima secesije i simbolizma te u slučaju Meštrovića i Račkoga monumentalizma i herojske ekspresije.

7 Meštrović je zapazio talent mladoga Nike Bodrožića iz Koljana kod Vrlike i poveo ga neko vrijeme sa sobom u Pariz na školovanje, a poslije mu je, zajedno s Vidovićem, pomogao da od općine Vrlika i Zemaljskog odbora izbori stipendiju za školovanje u Pragu. Mladi Dujam Penić pomagao je Meštroviću i Rosandiću na Ciklusu kraljevića Marka, a Tončić i Vidović pobrinuli su se da za boravka u Zagrebu mjesečno od Društva dobiva određeni novčani iznos.

8 SANDI BULIMBAŠIĆ (bilj. I, 20I6.), $75^{-} 77$.

9 Između ostalog, Društvo predlaže međunarodni žiri sastavljen od najboljih europskih kipara, anonimnost natječaja, nemogućnost odstupanja izvedbe od natječajnog rada, poštivanje umjetničke slobode u prikazu portretiranoga. Opširnije: SANDI BULIMBAŠIĆ (bilj. I, 20I6.), 6I-64.

Io Danas kavana Central u jugoistočnom dijelu Pjace.

II ANONImNo, Veliki izlet u Italiju, u: Sloboda, 24. lipnjargı., zaseban dodatak, bez paginacije. 
Posebno treba istaknuti nastojanja medulićevaca u promicanju nacionalne umjetnosti osnivanjem umjetničkih zbirki i institucija koje će o nacionalnoj baštini i suvremenom likovnom stvaralaštvu skrbiti i prezentirati ih na primjeren način. Za razliku od Meštrovićeva zanosa vidovdanskom utopijom i elitističkog projekta podizanja hrama toj ideji, Vidovićeva, Tončićeva i Tartagliina nastojanja u organizaciji umjetničkog života u Splitu bila su praktična i dalekosežna. Osnivanje Obrtne škole, Etnografskog muzeja i Galerije umjetnina u Splitu njihova je zasluga. Ideja o Galeriji umjetnina začeta I9o8. na Prvoj dalmatinskoj umjetničkoj izložbi u Splitu, na kojoj su otkupljene i prve umjetnine, ponovno je aktualizirana na Izložbi jugoslavenskih umjetnika iz Dalmacije ı9ı9., a realizirana tek I93I. na čelu s tada već bivšim medulićevcima-Kamilom Tončićem kao prvim ravnateljem i Angjelom Uvodićem kao prvim kustosom, u vrijeme kada je Ivo Tartaglia imenovan banom Primorske banovine. Važna su i nastojanja Vidovića, Tončića, Katunarića i Meneghella Dinčića oko gradnje umjetničkog paviljona u Splitu koji bi služio za izložbe i buduću galeriju. Iako su I9I2. pregovarali sa splitskom općinom o zemljištu i novcu za gradnju izložbenog paviljona, do toga, nažalost, nije došlo. ${ }^{12}$ Nerealizirana je ostala i gradnja zgrade Etnografskog muzeja i Obrtne škole za koju je Kamilo Tončić igiı. napravio idejnu skicu. ${ }^{13}$ Materijalne i teške povijesne okolnosti u kojima se nalazila Dalmacija nisu pogodovale takvim nastojanjima.

Slika I

Hrvatski i slovenski umjetnici ispred Jakopičeva paviljona u Ljubljani foto: F. Vesel, rgog., Fototeka Narodnog muzeja Slovenije, Ljubljana, inv. br. N

29927

Slika 2

Nadežda Petrović pored Meštrovićeve skulpture Majka na Četurtoj jugoslavenskoj umjetničkoj izložbi u Beogradu, ıgı2. preuzeto iz: KATARINA AMBROZIĆ, Nadežda Petrović, Beograd, I978., 37I

Jedan od ciljeva definiranih pravilnikom Medulića bilo je i razvijanje suradnje s umjetničkim udruženjima u inozemstvu. Društvo je imalo dobru suradnju s regionalnim umjetničkim društvima u Sloveniji i Srbiji: Klubom Sava, koji je I9o3. u Ljubljani okupio slovenske impresioniste, Jugoslavenskom umjetničkom kolonijom utemeljenom ıgo4. u Sićevu kod Niša i Srpskim umjetničkim udruženjem osnovanim u Beogradu I907. Članovi navedenih udruženja međusobno su fluktuirali i većinom su pored članstva u nacionalnom udruženju bili i članovi Društva Medulić, koje je i tako uistinu imalo južnoslavenski karakter i ulogu središnjega južnoslavenskog umjetničkog udruženja (sl. I i 2 ). Zahvaljujući Meštroviću i Bukovcu, Društvo je ostvarilo kontakte i s inozemnim srednjoeuropskim društvima koja su imala slične ciljeve: afirmaciju modernizma i
I2 Prvi umjetnički izložbeni salon u Splitu, Salon Galić, izgrađen je privatnom inicijativom Ivana Galića I924. u Marmontovoj ulici i svečano je otvoren izložbom Emanuela Vidovića i Angjela Uvodića. Za umjetnički život Splita imao je značenje koje je Salon Ullrich imao u Zagrebu. I danas se tu održavaju izložbe u organizaciji HULU Split.

I3 Jug, 2 (I9II.), 63
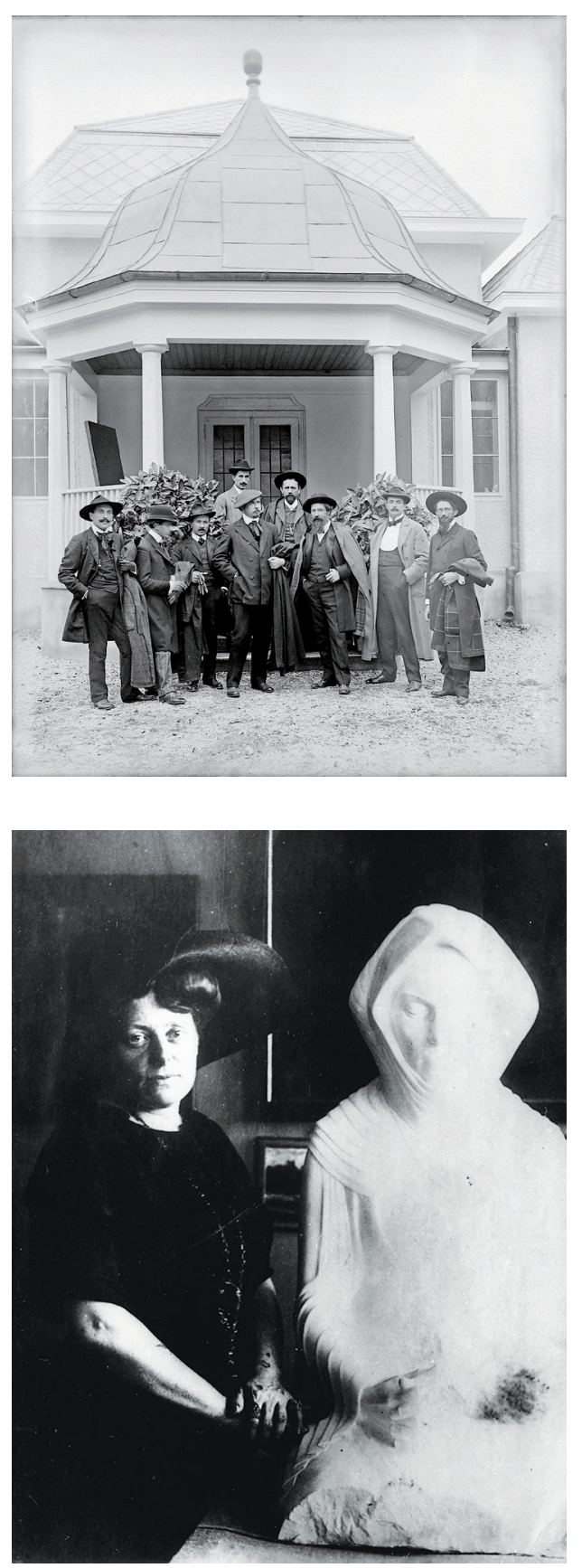

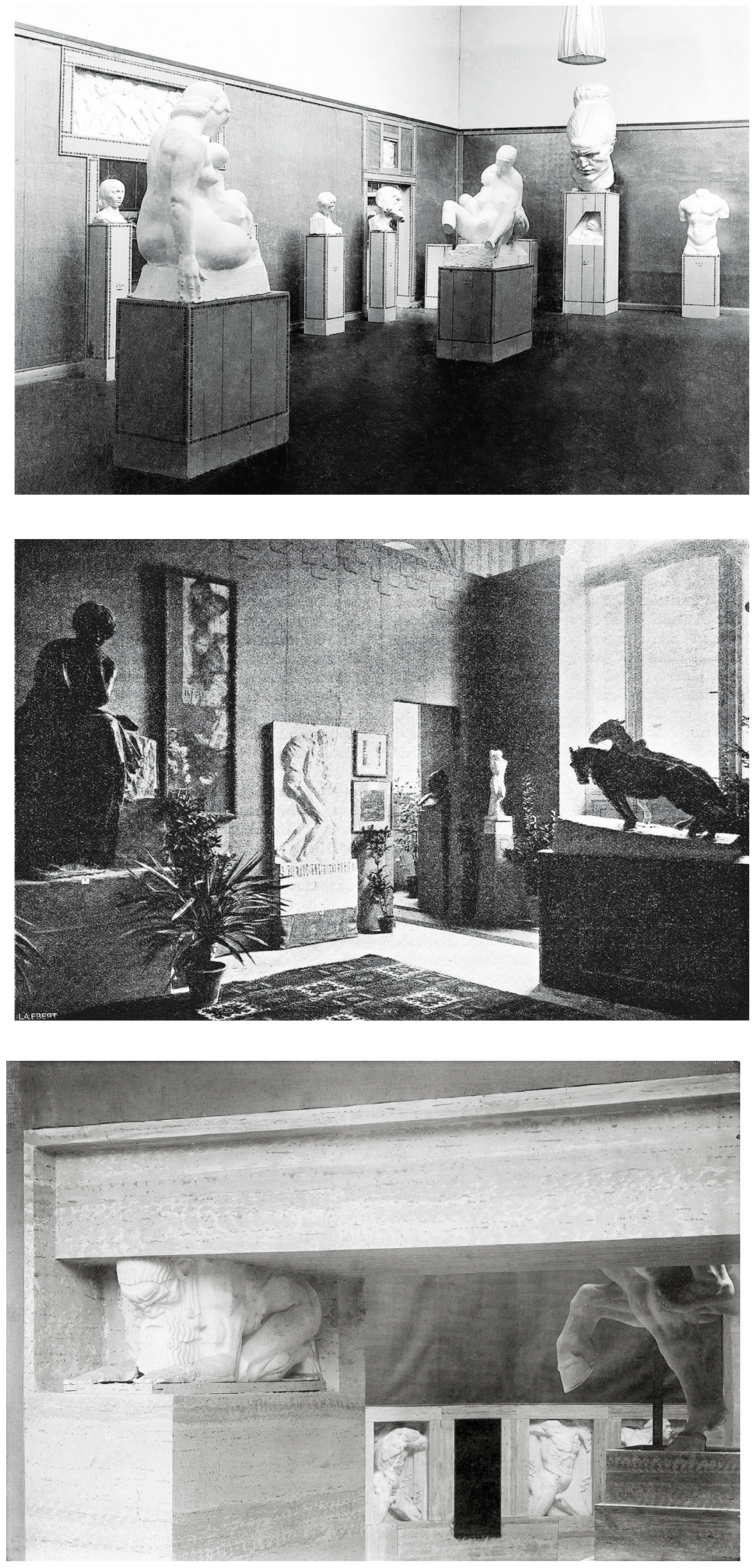

Slika 3

Postav samostalne izložbe Ivana Meštrovića, XXXV. izložba Secesije u Beču, Igro.

Fototeka Galerije Meštrović, Split, FGM-IO32

\section{Slika 4}

Postav Prve dalmatinske umjetničke izložbe foto: A. Katunarić, preuzeto iz: Erdgeist, Wien, br. 25, 28. studenoga I908., 966

\section{Slika 5}

Postav izložbe u paviljonu Kraljevine Srbije,

Međunarodna izložba, Rim, I9II Fototeka Galerije Meštrović, Split, FGM-975 
oblikovanje nacionalnog identiteta u umjetnosti. Pored Društva čeških umjetnika Manes s kojim su Bukovac i Meštrović izlagali u Pragu, ${ }^{14}$ nešto aktivniju suradnju Društvo Medulić ostvarilo je s Udruženjem umjetnika Moravske, utemeljenim I907. u Hodoninu, na čelu sa slikarom Jožom Uprkom, koji je kao član Medulića izlagao na središnjoj programskoj izložbi Društva Nejunačkom vremenu u prkos u Zagrebu igio. Meštrović i Uprka planirali su i zajedničke izložbe i članstvo dvaju društava, ali ih nisu uspjeli ostvariti. ${ }^{15}$

\section{Izložbe Društva Medulić}

Daleko najveći doprinos koji je Društvo Medulić ostvarilo u promicanju i prezentaciji nacionalne umjetnosti u zemlji i inozemstvu bile su izložbe Društva. Djelovanjem kroz bogatu izložbenu aktivnost Društvo Medulić izdvajalo se među suvremenim društvima u Hrvatskoj, susjednoj Sloveniji i Srbiji. Na ukupno osam realiziranih izložaba Društvo je uspostavilo nove kriterije izložbene prakse. ${ }^{16}$ Koliko je živa bila izložbena djelatnost Medulića potvrđuju i nerealizirane izložbe Društva planirane između I9I2. i I9I5.-kod pojedinih su pripreme već bile daleko odmaknule od početne ideje. ${ }^{17}$ Izložbe Društva Medulić svojom su organizacijom pridonijele, još od Hrvatskog salona I898., započetom procesu uspostavljanja inovativnih likovnih rješenja kojem su, prije Medulića, svoj doprinos dale i izložbe Saveza jugoslavenskih umjetnika Lada.

Na izložbama je Društvo, ponajprije zahvaljujući Ivanu Meštroviću i njegovu iskustvu stečenu na izložbama bečke Secesije, uvelo nove kriterije i visoke standarde u organizaciji, idejnom konceptu, dizajnu postava, plakata, pozivnice i kataloga izložbe. Meštrovićeve su zasluge u osuvremenjivanju likovnog postava izložaba preglednost, jednostavnost i jasnoća, simetričan raspored umjetnina, dobro dizajnirani postamenti te apostrofiranje ideje u predstavljanju umjetničkih djela (sl. 3). Za uočavanje njegova doprinosa dovoljno je usporediti Vidovićev postav izložaba Medulića u Splitu i Ljubljani ıgo8. i ı9og., zagušen prevelikim brojem asimetrično raspoređenih djela, ukrasnim lončanicama i tepisima, s Meštrovićevim postavom izložaba u Zagrebu igı. i Rimu igı I ${ }^{18}$ (sl. 4 i 5).

Svijest medulićevaca o važnosti ukupnog dojma dizajna izložbe očituje se i u pristupu oblikovanju i sadržaju kataloga i plakata, kada su im materijalne prilike dopuštale. Katalozi izložaba Društva Medulić koje prema uzoru na kataloge izložaba bečke Secesije najčešće oblikuju Meštrović i Krizman, u hrvatskoj su umjetnosti označili prijelomni trenutak i na tom polju. Izvan dotad uvriježenih skromnih kataloga samo s popisom izlagača i izloženih djela, većina kataloga izložaba Medulića imala je kvalitetno dizajnirane naslovnice, velik broj reprodukcija izloženih radova, predgovor te ponekad životopise i portrete izlagača. ${ }^{19}$ Kvalitetom i opremom ističu se katalozi Izložbe Meštrović-Rački, Nejunačkom vremenu u prkos i izložbe u paviljonu Kraljevine Srbije na Međunarodnoj izložbi u Rimu ${ }^{20}$ (sl. 6a, b, c). Među plakatima ističu se Meštrovićev plakat s likom
I4 Izlagali su I9o8. i I9og. na izložbama u organizaciji bečkog udruženja Hagenbund. IRENA KRAŠEVAC, Ivan Meštrović i secesija. Beč-München-Prag I9oo-ı9ıo, Zagreb, 2002., I59. Opširnije o Manesu i Meduliću: SANDI BULIMBAŠIĆ (bilj. I, 20I6.), 356. I5 Opširnije: SANDI BULIMBAŠIĆ (bilj. I, 20I6.), 357 .

I6 Prua dalmatinska umjetnička izložba u Splitu I9o8., Izložba Društva hrvatskih umjetnika „Medulić” u Ljubljani I9og., Izložba Meštrović-Rački i Nejunačkom vremenu u prkos u Zagrebu I9ı., Međunarodna izložba u Rimu I9II., Četurta jugoslavenska umjetnička izložba u Beogradu ı9ı2., Izložba jugoslavenskih umjetnika iz Dalmacije i Izložba Vidovića u Splitu ıgıg.

I7 Izložba humanitarnog karaktera za djecu vojnika stradalih u Balkanskom ratu u Splitu I9ı2., Izložba Društva „Medulić” i Društva „Marjan”, Posthumna retrospektivna izložba Ivana Grohara u Splitu, I9I3. Izložba Ivana Meštrovića u Splitu I9I4., Izložba Društva hrvatskih umjetnika „Medulić” u Zagrebu I9I5., koja je trebala imati programski nacionalni karakter kao i izložba Nejunačkom vremenu u prkos.

I8 Te su izložbe, osim već navedenih karakteristika jednostavnosti i jasnoće, imale i svoje scenične detalje poput bisti ovjenčanih lovorovim vijencima, pred zlatnom pozadinom, naslikanim prizorom zlatnog izlazećeg sunca i ljudi koji mu se klanjaju u dnu Meštrovićeve Aleje karijatida itd. Opširnije: SANDI BULIMBAŠIĆ (bilj. I, 20I6.), 323-324.

I9 Portrete i biografije članova sadržava katalog Prve dalmatinske umjetničke izložbe u Splitu. U katalogu izložbe u Ljubljani su, unatoč Vidovićevoj želji, izostali jer Rihard Jakopič, koji je izložbu sam financirao, nije imao novca za bolju opremu kataloga.

20 Opširnije: SANDI BULIMBAŠI ́́ (bilj. I, 20I6.), 324-325. 

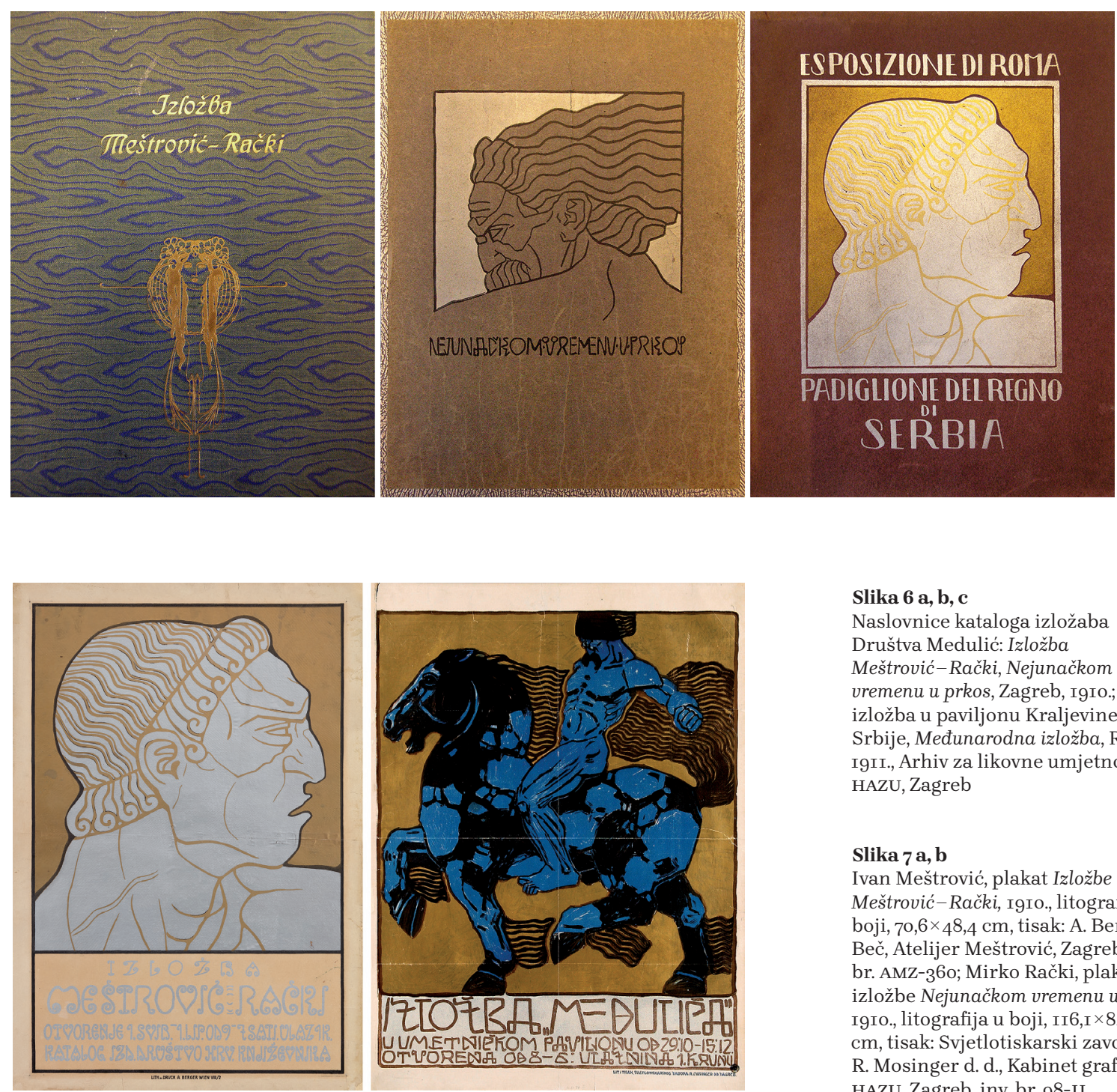

Slika 6 a, b, c

Naslovnice kataloga izložaba Društva Medulić: Izložba Meštrović-Rački, Nejunačkom vremenu u prkos, Zagreb, I9ıо.; izložba u paviljonu Kraljevine Srbije, Međunarodna izložba, Rim, IgII., Arhiv za likovne umjetnosti HAZU, Zagreb

Slika 7 a, b

Ivan Meštrović, plakat Izložbe Meštrović-Rački, I9io., litografija u boji, 7o, $6 \times 48,4 \mathrm{~cm}$, tisak: A. Berger, Beč, Atelijer Meštrović, Zagreb, inv br. AMZ-36o; Mirko Rački, plakat izložbe Nejunačkom vremenu u prkos, I9ıо., litografija u boji, II6,I $\times 84,2$ $\mathrm{cm}$, tisak: Svjetlotiskarski zavod R. Mosinger d. d., Kabinet grafike HAZU, Zagreb, inv. br. 98-II

Srđe Zlopogleđe za Izložbu Meštrović-Rački i plakat Mirka Račkoga s likom Meštrovićeva Kraljevića Marka za izložbu Nejunačkom vremenu u prkos. Ti su plakati secesijske stilizacije oblikovanjem i izborom motiva mitskih junaka iz narodnog epa dodatno isticali medulićevsku ideju nacionalne umjetno$\operatorname{sti}^{21}$ (sl. 7 a, b).

Od prve do posljednje izložbe Medulića ravnopravno su bili zastupljeni različiti likovni mediji; uz slikarstvo, skulpturu i grafiku izlagani su i predmeti umjetničkog obrta, arhitektu$\mathrm{ra}^{22}$ te kao svojevrsna posebnost karikatura. Na izložbama i u listu Duje Balavac medulićevci su predstavljali karikaturiste splitskog kruga, ali i autore iz Zadra i Šibenika, pridonijevši recepciji karikature među publikom i likovnom kritikom. O iznimnosti i značenju onodobnoga ravnopravnog izlaganja karikature na izložbama Društva Medulić te otkupa za fundus

2I LADA KAVURIĆ, Hrvatski plakat do I940., Zagreb, I999., IO2; LADA KAVURIĆ, Stoljeće hrvatskog plakata, katalog izložbe, (ur.) Slavica Marković, Zagreb, 200I., 7,36 .

22 Za odjel umjetničkog obrta na izložbama najzaslužniji su Kamilo Tončić i Tomislav Krizman. Arhitekti, iako članovi Društva, nisu sudjelovali često ni u većem broju. 

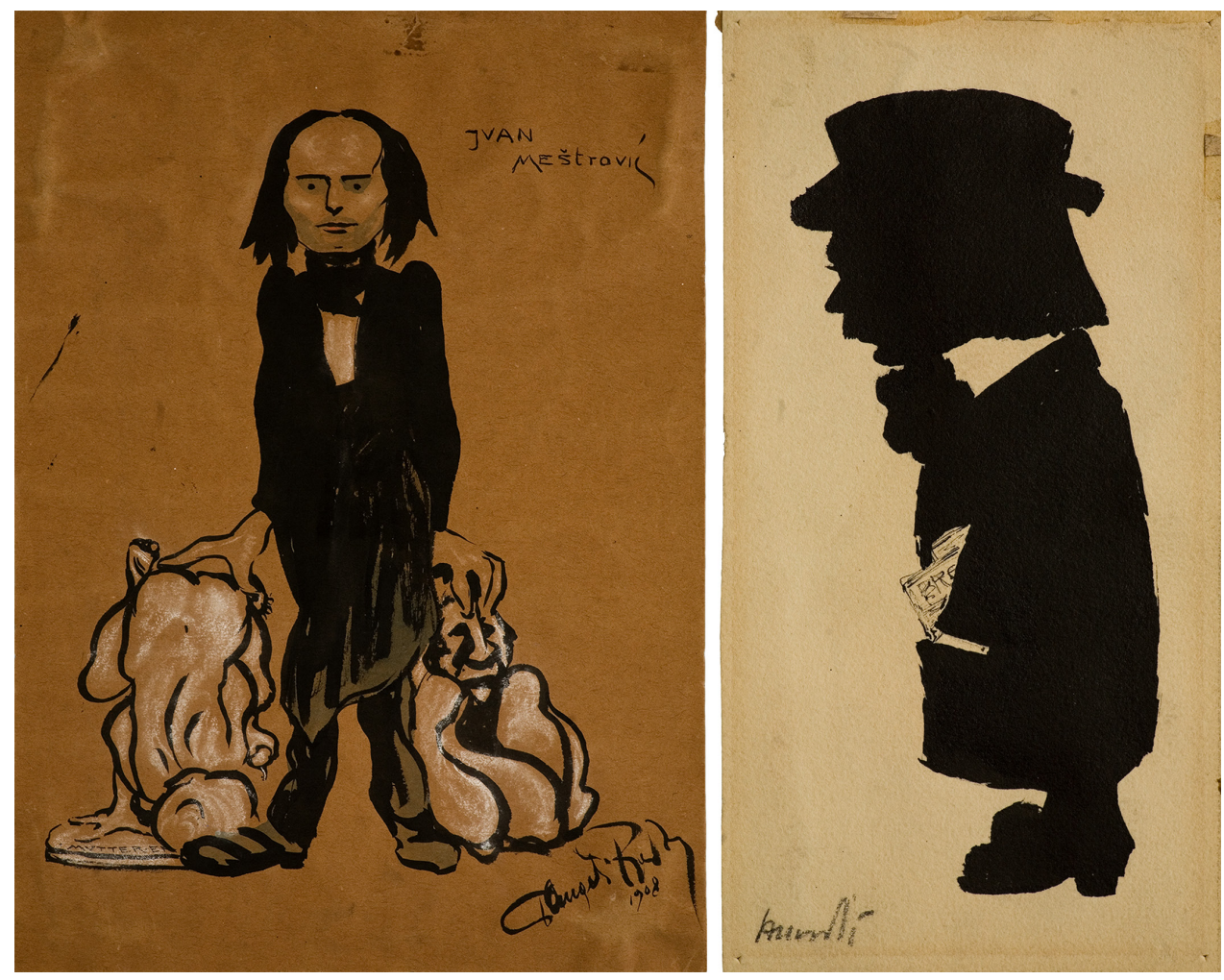

Slika 8 a, b

Frano Branko Angeli Radovani,

Karikatura Ivana Meštrovića, I9o8.,

tuš, kist, akvarel, kreda/papir,

$44,2 \times 3 \mathrm{I}, 6 \mathrm{~cm}$, Galerija umjetnina

Split, inv. br. 1705; Angjeo Uvodić,

Karikatura Ive Tartaglie, I9o8.(?), tuš, kist, pero/papir, $18 \times 9,4 \mathrm{~cm}$, Galerija umjetnina Split, inv. br. I3II,

foto: V. Bilić Prcić, Fototeka Galerije umjetnina Split

buduće Galerije umjetnina na izložbama u Splitu ı9o8. i ı9ı9. dovoljno govori činjenica da je karikatura kao likovni medij još dugo, desetljećima nakon prestanka djelovanja Društva, ostala zapostavljena u hrvatskoj umjetnosti i povijesti umjet$\operatorname{nosti}^{23}$ (sl. 8 a, b).

Na izložbama Medulića, ravnopravno s muškim kolegama, izlagale su i umjetnice. ${ }^{24}$ Ipak, njihovi životopisi ili portreti nisu nikad bili uključeni u kataloge. Većinom je riječ o plemkinjama ili slikaricama iz imućnijih građanskih obitelji koje su se školovale na skupim privatnim školama u zemlji i inozemstvu jer zagrebačka Akademija prima žene tek od osnutka I9o7., kada su umjetnice o kojima je ovdje riječ svoje školovanje već završile: Rita Bersa-Bottura, Dome Suhor, Flora Jakšić, Amelia Knežević Bogdanović, Zoe Borelli Vranska Alačević, Anka Bestall, Vjera Bojničić Kninska, Greta Ritter, Ada i Renée

23 FRANO DULIBIĆ, Splitski krug karikaturista (I9oo. - I940.), u: Peristil, 46 (2003.), I27-I44; FRANO DULIBIĆ, Povijest karikature u Hrvatskoj do I940. godine, Zagreb, 2009 .

24 Na Prvoj dalmatinskoj umjetničkoj izložbi u Splitu izlagale su četiri slikarice, na središnjoj izložbi Medulića u Zagrebu devet umjetnica, na Međunarodnoj izložbi u Rimu dvije. Najveći broj umjetnica, njih dvanaest, s dotad najvećim brojem izloženih radova po umjetnici, prisutan je na Četurtoj jugoslavenskoj umjetničkoj izložbi u Beogradu ıgı2. Većinom je riječ o polaznicama Krizmanove privatne umjetničke škole, koje su izlagale u odjelu primijenjene umjetnosti. Na izložbi u Splitu Igrg. izlagala je jedino Zoe Borelli. 
Vranyczany, Anka Krizmanić. S iznimkom Anke Krizmanić i Nadežde Petrović, ključne protagonistice srpske moderne, riječ je o manje poznatim hrvatskim umjetnicama koje postupno dolaze u središte znanstvenog zanimanja istraživača. ${ }^{25}$ Praćenjem kritičke recepcije njihove umjetnosti kroz izložbe Društva Medulić zaključujemo da nije bila rodno određena, ${ }^{26}$ a s obzirom na stvarne kvalitativne umjetničke dosege navedenih hrvatskih umjetnica, suvremeni su ih kritičari ponekad pretjerano hvalili. Hrvatska je kulturna javnost osobito pomno pratila rad kontese Zoe Borelli, koja je redovito izlagala s medulićevcima, posebice njezine karikature i studije narodnih nošnji ${ }^{27}$ (sl. g).

\section{Nacionalna umjetnost i mobilizacijska uloga Društva Medulić u hrvatskoj povijesti umjetnosti}

Izložbe Društva Medulić i njihov odjek u javnosti i likovnoj kritici svjedoče o postupno sve izraženijoj političkoj ideji ujedinjenja južnoslavenskih naroda i oblikovanja nacionalnog izraza u umjetnosti. Meštrovićevo sve angažiranije političko djelovanje, rad na Vidovdanskim fragmentima i Ciklusu kraljevića Marka te ideja podizanja Vidovdanskog hrama kao simbola narodnog oslobođenja djelovali su, u razdoblju do Prvoga svjetskog rata, mobilizacijski na cijelu generaciju umjetnika u Hrvatskoj i na prostoru nekadašnje Jugoslavije. Nacionalni politički program medulićevaca okupio je ne samo umjetnike nego i istaknute političare, intelektualce, književnike i likovne kritičare. U likovnoj je kritici, u tekstovima
25 Temelj za istraživanje njihovih opusa jest zbirka dr. Josipa Kovačića Hrvatske slikarice rođene u I9. stoljeću, koja sadržava Io45 djela 33 autorica. Vidi: Hruatske slikarice rođene u XIX. stoljeću: donacija Josipa Kovačića, katalog izložbe, (ur.) Lea Ukrainčik, Zagreb, I988.; Hruatske slikarice plemkinje iz Zbirke dr. Josipa Kovačića, katalog izložbe, (ur.) Zdravko Mihočinec,Zagreb, 2002.; DARIJA ALUJEVIĆ, Kiparica Renée Vranyczany-Dobrinović, u: Peristil, 57 (20I4.), I59-I69; VINICIJE B. LUPIS, SANJA ŽAJA VRBICA, Prilog poznavanju prvih dubrovačkih slikarica, u: Anali Zavoda za povijesne znanosti HAZU u Dubrouniku, 52/2 (20I4.), 52I-548; DARIJA ALUJEVIĆ, Beč kao mjesto formiranja umjetnica hrvatske moderne i njihov udio u likovnom životu Zagreba, u: Izazou moderne: Zagreb-Beč oko Igoo. Slikarstvo, kiparstvo i arhitektura zagrebačke i bečke secesije, katalog izložbe, (ur.) Irena Kraševac, Petra Vugrinec, Zagreb, 20I7., I25-I47.

26 Iznimka su osvrti slovenskih kritičara Vladimira Levstika i Frana Kobala u povodu izložbe Medulića u Ljubljani I9o9. SANDI BULIMBAŠIĆ (bilj. I, 20I6.), I6o.

27 Temeljni podaci o slikarici: DARIJA ALUJEviĆ (bilj. 25, 20I7.), I46-I47.

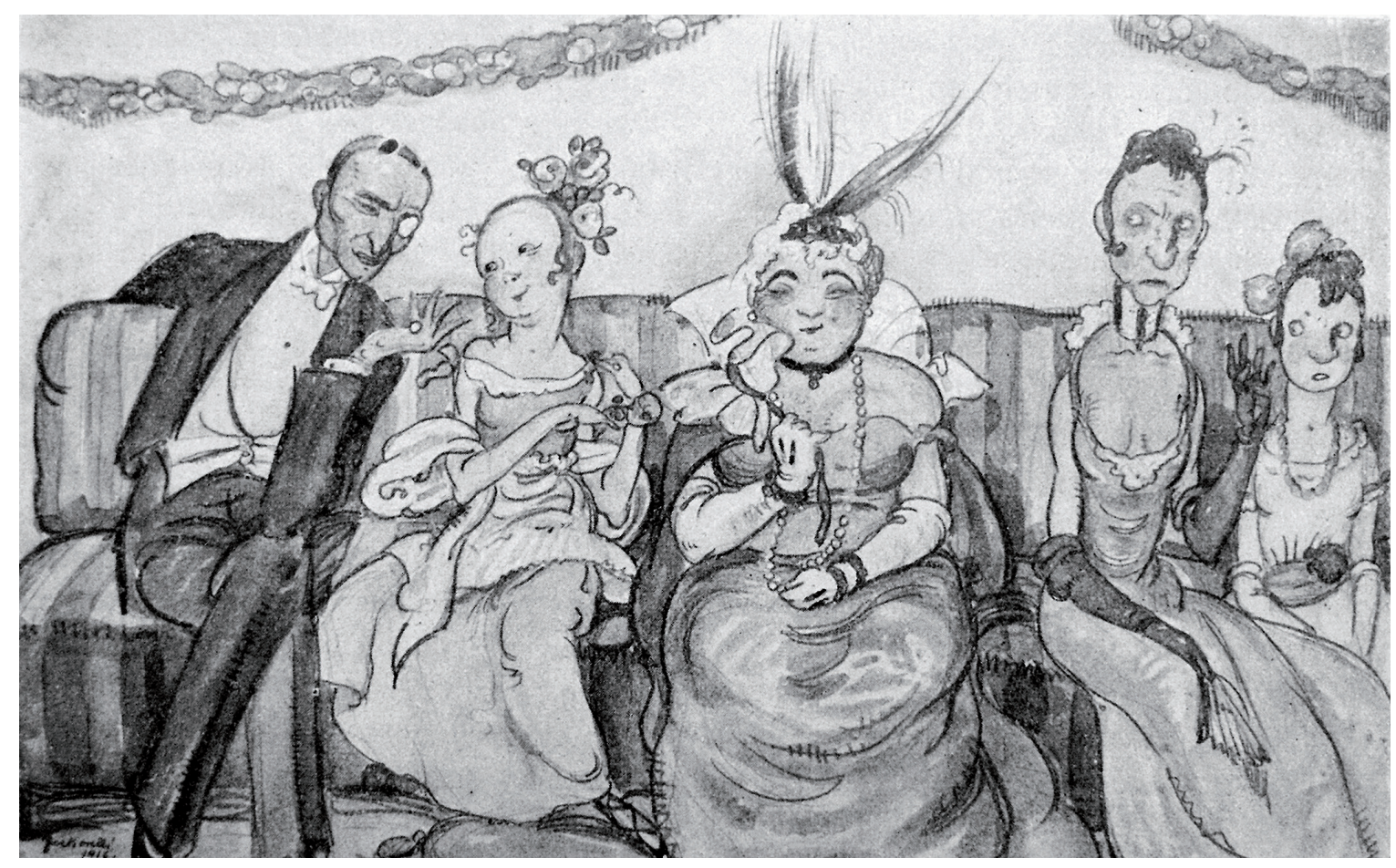


Meštrovićevih najgorljivijih promotora, Milana Marjanovića i Dimitrija Mitrinovića, i nastao pojam „nacionalni” izraz i „nacionalna" umjetnost. Ivan Meštrović i njegova umjetnost s izvedbom monumentalnih djela nadindividualne ekspresije i kolektivne identifikacije postigli su široku umjetničku i idejnu prepoznatljivost.

\section{Napredna uloga Društva u razvoju umjetnosti u Hrvatskoj}

Medulićevci su imali velik utjecaj na razvoj umjetnosti u Hrvatskoj, ne samo u vrijeme u kojem su djelovali nego i u sljedećim desetljećima. Zbog otvorenosti novim idejama i razvojnim pomacima te njegovanju umjetničke slobode otvorili su put ekspresionizmu, metafizičkom slikarstvu, futurizmu i kubizmu. Ti se pravci afirmiraju u okrilju mlađih pristaša medulićevaca (Jerolim Miše, Marino Tartaglia, Vinko Foretić...), koji izlažu na posljednjoj izložbi Društva Medulić u Splitu rgıg., a nastavljaju izlagati i na izložbama Proljetnog salona u Zagrebu² (sl. Io).

* Promicanjem i zaštitom staleških interesa, zahtjevom za uvođenjem visokih profesionalnih standarda i slobodom izbora individualnog izraza likovni život u Hrvatskoj postao je bujniji, raznovrsniji i kvalitetniji. Taj zamah prepoznavao se na izložbama Društva Medulić, koje postaju sve češće i osvajaju temama prepoznatljivih nacionalnih krajolika, narodnih običaja, lokalnih tradicija ostvarenih spontanošću pristupa i svježinom jezika koji smanjuje razlike između velikih kulturnih centara i periferije.

Impuls vrijednosne afirmacije nacionalnih doprinosa u zemlji i inozemstvu, s kojim je Društvo Medulić učinilo važan iskorak, zasluga je, u prvom redu, primjera i uloge Ivana Meštrovića. Samosvojnost Meštrovićeve kiparske geste, herojske emanacije i tektonske kondenzacije forme i danas impresionira djelovanjem panteonske svevremenosti, uz lučonoše novih vrijednosti poput Emanuela Vidovića, Tomislava Krizmana, Mirka Račkog, slovenskih impresionista Riharda Jakopiča i Ivana Grohara i osobito, za vrijeme Prvoga svjetskog rata prerano preminule, srpske slikarice Nadežde Petrović. Njihov zanos, motivacijska, intelektualna i umjetnička zrelost uključivosti i prihvaćanja novog duha i njegovih obrazaca, osigurali su Društvu Medulić status važnoga kulturnog „projekta” kao iskoraka i ostavštine budućim naraštajima.

Ovaj rad je sufinancirala Hrvatska zaklada za znanost projektom br. 4I53, Croatia and Central Europe: Art and Politics in the Late Modern Period (I780-I945).
28 Tartaglia je svoje metafizičke slike prvi put izložio u Splitu ı9ı9., a ne, kako se dosad navodilo, na Proljetnom salonu iste godine: SANDI BULIMBAŠIĆ (bilj. I, 20I6.), 308-310. Ne treba zaboraviti ni da su upravo medulićevci među utemeljiteljima i prvim, najbrojnijim, izlagačima Proljetnog salona ı9ı6.

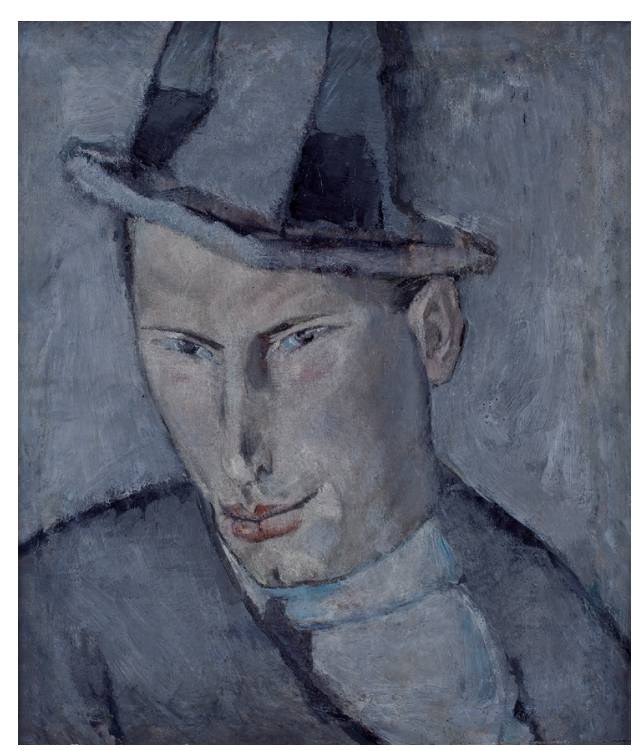

Slika Io

Marino Tartaglia, Portret Mate Meneghella Rodića, I9I9. ulje na platnu, $33^{\times} 28 \mathrm{~cm}$, Galerija umjetnina Split, inv. br. 723 , foto: A. Verzotti, Fototeka Galerije umjetnina Split

\section{(c) (i)}

Društvo hrvatskih umjetnika Medulić-artikulacija programa/Sandi Bulimbašić / CC BY / 4.0

DOI: https://doi.org/Io.3I664/z4khpu.33 